AGH DRILLING, OIL, GAS • Vol. 35 • No. $1 \cdot 2018$

http://dx.doi.org/10.7494/drill.2018.35.1.69

\author{
Łukasz Łukańko*, Jan Macuda*
}

\title{
EMISSION OF POLLUTANTS INTO THE AIR DURING EXPLORATION OF COALBED METHANE**
}

\section{INTRODUCTION}

In recent years increased attention has been pay to air pollution in Poland. More and more often we hear new information about the disastrous state of air quality in the vicinity of large urban agglomerations. Based on WHO data from 2013, 33 of the 50 most polluted cities by PM2.5 in Europe are in Poland [11]. The most dangerous pollutants reaching ambient air include mainly dust PM10, PM2.5 and benzo(a)pyrene, which is a strongly carcinogenic compound. In Poland, poor condition of the air is influenced by industry, transport and pollution produced during the combustion of poor quality coal in households. Most of the previously mentioned cities in Poland, with poor air quality are located in the Upper Silesian Coal Basin area [10]. The lack of alternative energy sources means that the main source of energy in this region is coal.

A source of clean energy could be a methane adsorbed in coal. In Poland, the economic use of methane from coal seams has been recognized as one of the priority objectives of energy policy. According to documentation in the Upper Silesian Coal Basin, documented methane resources in coal seams are 89.1 billion $\mathrm{m}^{3}$ [4].

Recently, after the failures of foreign investors such as Texaco or Amoco in the 1990s, a new attempts were made to obtain methane from coal seams [2]. New research operations were carried out using drilled wells Wesoła PIG-1 and Wesoła PIG-2H and Gilowice-1 and Gilowice-2H [3]. The first project did not bring the expected results, while the Gilowice project allowed methane production at a level of $5000 \mathrm{~m}^{3}$ a day [8].

AGH University of Science and Technology, Faculty of Drilling, Oil and Gas, Krakow, Poland

** Work performed within AGH UST statutory research program no. 11.11.190.555 
The consortium PGNiG and PIG-PIB is planning to continue research, related to the extraction of methane from coal seams. Methane from coal seams is extracted using a pair of wells - a vertical one which is used to extract methane and reservoir water, and a horizontal one which is used as a drainage well [2]. In order to increase the production of methane, hydraulic fracturing should be carried out. Drilling and hydraulic fracturing operations are carried out with drilling equipment and high-pressure pumps, which are powered by combustion engines of very high power. One negative result of this work is the emission of pollutants in to the air.

\section{METHODOLOGY FOR AIR POLLUTION MODELING}

Emission of pollutants to the air is determined on the basis of the reference methodology for modeling levels of substances in the air, described in the Regulation of the Minister of the Environment regarding reference values for certain substances in the air (Journal of Laws No. 16 item 87 of January 26, 2010). The concentration of the gaseous substance for one hour at the point $X p, Y p, Z p$ is calculated using formula (1) [6]:

$$
S_{x y z}=\frac{E_{g}}{2 \cdot \pi \cdot u \cdot \sigma_{y} \cdot \sigma_{z}} \exp \cdot\left(-\frac{y^{2}}{2 \cdot \sigma_{y}^{2}}\right)\left\{\exp \cdot\left[-\frac{(z-H)^{2}}{2 \cdot \sigma_{z}^{2}}+\exp \cdot\left[-\frac{(z+H)^{2}}{2 \cdot \sigma_{z}^{2}}\right]\right]\right\} \cdot 1000
$$

where:

$S_{x y z}$ - concentration of (gaseous) contamination at point $(x, y, z)$ during 1 hour period $\left[\mu \mathrm{g} / \mathrm{m}^{3}\right]$,

$E_{g}-$ contamination emission $[\mathrm{mg} / \mathrm{s}]$,

$H$ - effective height of emitor [m],

$u$ - average wind velocity in an air layer from $z=h$ to $z=H[\mathrm{~m}]$,

$y$ - the component of the emitter's distance from the point for which the calculation is made, perpendicular to the direction of the wind [m],

$z$ - height for which the concentration of the substance in the air is calculated [m],

$\sigma_{y}-$ horizontal diffusion coefficient [m],

$\sigma_{z}-$ vertical diffusion coefficient $[\mathrm{m}]$.

On the basis of the obtained results, the range of calculation of the substance levels in the air is checked, which includes the shortened range and the full range. If the preliminary calculation shows that the conditions defined in the formula (2) are fulfilled, then calculation are finished [6]:

$$
S_{m m} \leq 0.1 \cdot D_{1} \quad \text { or } \quad \sum_{e} S_{m m} \leq 0.1 \cdot D_{1}
$$


If the conditions of the shortened range are not meet the requirements, the distribution of the maximum concentrations of substances in the air for one hour, including the statistics of meteorological conditions, should be calculated over the entire area to check whether at each point on the land surface has been meet condition defined by formula (3) [6]:

$$
S_{m m} \leq D_{1}
$$

If the calculations shows that the condition described in the formula 4 is fulfilled for the emitters, then the calculation should be finished [6]:

$$
S_{m m} \leq 0.1 \cdot D_{1}
$$

For a group of emitters which condition (4) is not fulfilled or for a single emitter for which the condition specified in the shortened range is not meet, should be calculated the distribution of air concentrations and checked whether at each point of the surface has been meet for the average annual concentrations specified by formula (5) [6]:

$$
S_{a} \leq D_{a}-R
$$

Acceptable levels of substances in the air are considered to be meet, if the frequency of exceeding $D_{1}$ by averaged over one hour is not more than $0.274 \%$ of the time of the year for sulphur dioxide and $0.2 \%$ of time per year for other substances [6]. In case the concentration caused by substance emission from all emitters exceeds a reference value or the permissible level of a substance in the air and the frequency of exceeding the $P\left(D_{1}\right)$ is calculated. Acceptable frequency of exceeding of $D_{1}$ is maintained, if the calculated $99.8 \%$ percentile of one hour concentrations $\left(S_{99.8 \%}\right)$ is lower than the reference value or the permissible level of substances in the air. This means that for substances whose concentrations do not meet the criteria (4), should be verified by following criteria to set out in formulas (6), (7) and (8) [6]:

$$
\begin{gathered}
S_{m m} \leq D_{1} \\
S_{99.8 \%} \leq D_{1} \\
S_{a} \leq D_{a}-R
\end{gathered}
$$

Due to the legal regulations in Poland, emission of pollutants from devices used for extraction of coal bed methane should meet standards regarding concentrations of pollutants into the air. The reference values of the concentrations of substances emitted 
should not exceed the values specified in the polish law. The admissible values for the analyzed substances in air have been presented in Table $1[6,7]$.

Table 1

Admissible value for substances in air $[6,7]$

\begin{tabular}{|c|c|c|c|}
\hline \multirow{2}{*}{ Pollutant } & \multicolumn{3}{|c|}{ Admissible value } \\
\cline { 2 - 4 } & $\begin{array}{c}\text { Max 1-hour } \\
\text { concentrations }\end{array}$ & $\begin{array}{c}\text { Average yearly } \\
\text { concentrations }\end{array}$ & $\begin{array}{c}\text { Incidence of exceeding } \\
\text { admissible values }\end{array}$ \\
\cline { 2 - 4 } & $D_{1}$ & $D_{a}$ & $P\left(D_{1}\right)$ \\
\cline { 2 - 4 } & {$\left[\mu \mathrm{g} / \mathrm{m}^{3}\right]$} & {$\left[\mu \mathrm{g} / \mathrm{m}^{3}\right]$} & {$[\%]$} \\
\hline $\mathrm{NO}_{2}$ & 200 & 40 & 0.2 \\
\hline $\mathrm{SO}_{2}$ & 350 & 20 & 0.274 \\
\hline $\mathrm{PM}_{0}$ & 280 & 40 & 0.2 \\
\hline $\mathrm{CO}$ & 30000 & 0 & 0.2 \\
\hline
\end{tabular}

\section{CALCULATION OF POLLUTION EMISSION INTO THE AIR}

The first advanced works related to the methane extraction from the coal seams in Poland were carried out in 2013-2015 [3]. The project was run by Polish Geological Institute together with Katowicki Holding Weglowy and consisted demethanization of coal seams. For this purpose, two wells were drilled for methane extraction from the coal seams. Wesoła PIG-1 well was drill as vertical one with a depth of 1000 m MD, whereas Wesoła PIG-2H was drilled as an open hole with horizontal section (1918 m MD/904 m TVD) [3]. Drilling time was 30 days and 45 days respectively [3]. In addition, eight hydraulic fracturing stage were carried out in the horizontal section. Another project was carried out in 2016-2017 by Polish Oil and Gas Company and Polish Geological Institute. Work involved, reconstruction of the Gilowice-2H well drilled in 2012, by Dart Energy and six-stage hydraulic fracturing operations. The drilling works for Gilowice-1 well (1088 m MD/1044.5 m TVD) took 17 days, while Gilowice-2H (2300 m MD/856 m TVD) was carried out for 28 days [2, 3]. Duration of hydraulic fracturing operation was 3 hours for each stage. For drilling operations of the Gilowice- 1 and Gilowice-2H, a Skytop Brewster TR-800 device was used. The drilling device was powered by two CAT 3408 engines - $500 \mathrm{HP}$ each, whereas the mud pumps were powered by 750 HP CAT D398 engine [1]. For hydraulic fracturing operations were used 6 high-pressure pumps driven by Stewart \& Stevenson FT-2251T engine - $2250 \mathrm{HP}$ and one blender driven by Stewart \& Stevenson MT-132HP engine 1450 HP [9]. Parameters of all emitters are presented in Table 2. 
Table 2

Characteristic of emitters $[1,9]$

\begin{tabular}{|l|c|c|c|c|}
\hline \multirow{2}{*}{ Parameter } & \multicolumn{2}{|c|}{ Drilling operations } & \multicolumn{2}{c|}{ Hydraulic fracturing } \\
\cline { 2 - 5 } & CAT 3408 & PZ-8 & FT-2251T & MT-132HP \\
\hline Amount of emitters [pcs] & 2 & 1 & 6 & 1 \\
\hline Horsepower rating [kW] & 367 & 552 & 1655 & 1066 \\
\hline Height of emitter [m] & 4.0 & 3.0 & 4.0 & 4.0 \\
\hline Diameter of emitter [m] & 0.3 & 0.3 & 0.4 & 0.4 \\
\hline Efficiency [\%] & 75 & 75 & 90 & 90 \\
\hline
\end{tabular}

For calculations emissions of particulate matter (PM10), sulphur dioxide $\left(\mathrm{SO}_{2}\right)$, nitrogen oxides $\left(\mathrm{NO}_{X}\right)$ and carbon monoxide $(\mathrm{CO})$, emission index presented in the "Large Stationary Diesel and All Stationary Dual-fuel Engines, Volume I, Chapter 3: Stationary Internal Combustion Sources" were used. The emission factors used in calculations are presented in Table 3.

Table 3

Emission factors for stationary diesel engines over $560 \mathrm{~kW}$ fed with diesel oil [10]

\begin{tabular}{|l|c|}
\hline \multicolumn{1}{|c|}{ Pollutant } & $\begin{array}{c}\text { Emission index referred to engine power (output) } \\
{[\mathrm{g} / \mathrm{kWh}]}\end{array}$ \\
\hline Nitrogen oxides $\left(\mathrm{NO}_{X}\right)$ & 7.904 \\
\hline Sulphur dioxide $\left(\mathrm{SO}_{2}\right)$, & $4.918 \cdot \mathrm{S}$ \\
\hline Particulate matter $(\mathrm{PM} 10)$ & 0.4261 \\
\hline Carbon monoxide $(\mathrm{CO})$ & 3.344 \\
\hline S - sulphur content in fuel $0.01 \%$ & \\
\hline
\end{tabular}

Results of hourly and annual emission of pollutants emitted to air from generators during drilling and hydraulic fracturing operations are presented in Table 4.

Specialized OPA03 software was used for modeling of pollutants spread in ambient air during extracting of methane from coal seams. Modeling of the spread of pollutants was carried out in the area where previous research works were carried out Upper Silesian Coal Basin. Important parameter required to calculate the spread of pollutants in the air is the background of pollution in interest area. For the considered 
area based on the WIOŚ data, the following background conditions of air pollution were adopted [12]:

- particular matter PM10 - $25 \mu \mathrm{g} / \mathrm{m}^{3}$,

- sulphur dioxide $\mathrm{SO}_{2}-8 \mu \mathrm{g} / \mathrm{m}^{3}$,

- nitrogen oxides $\mathrm{NO}_{2}-20 \mu \mathrm{g} / \mathrm{m}^{3}$.

For other substances, the background level was set at $10 \%$ of the permissible concentration in the air.

Table 4

Hourly and annual emission of pollutants emitted to air from generators

\begin{tabular}{|l|c|c|c|c|c|c|}
\hline \multirow{3}{*}{ Pollutant } & \multicolumn{2}{|c|}{$\begin{array}{c}\text { Vertical } \\
\text { drilling }\end{array}$} & \multicolumn{7}{c|}{$\begin{array}{c}\text { Horizontal } \\
\text { drilling }\end{array}$} & \multicolumn{2}{c|}{$\begin{array}{c}\text { Hydraulic } \\
\text { fracturing }\end{array}$} \\
\cline { 2 - 8 } & \multicolumn{7}{|c|}{ Emission of pollutants } \\
\cline { 2 - 8 } & {$[\mathrm{kg} / \mathrm{h}]$} & {$[\mathrm{Mg} / \mathrm{a}]$} & {$[\mathrm{kg} / \mathrm{h}]$} & {$[\mathrm{Mg} / \mathrm{a}]$} & {$[\mathrm{kg} / \mathrm{h}]$} & {$[\mathrm{Mg} / \mathrm{a}]$} \\
\hline $\mathrm{NO}_{2}$ & 10.16 & 4.15 & 10.16 & 6.83 & 60.75 & 1.56 \\
\hline $\mathrm{SO}_{2}$ & 0.00006 & 0.00003 & 0,00006 & 0.00004 & 0.00038 & 0.00001 \\
\hline $\mathrm{PM} 10$ & 0.55 & 0.22 & 0.55 & 0.37 & 3.28 & 0.085 \\
\hline $\mathrm{CO}$ & 4.30 & 1.75 & 4,30 & 2.89 & 25.70 & 0.61 \\
\hline $\begin{array}{l}\text { Vertical drilling: } 408 \mathrm{~h}, \text { Fuel consumption: } 0.047 \mathrm{~m}^{3} / \mathrm{h} \text { (drilling unit), } 0.079 \mathrm{~m}^{3} / \mathrm{h}(\mathrm{mud} \text { pump) } \\
\text { Horizontal drilling: } 672 \mathrm{~h} \text {, Fuel consumption: } 0.047 \mathrm{~m}^{3} / \mathrm{h} \text { (drilling unit), } 0.079 \mathrm{~m}^{3} / \mathrm{h}(\mathrm{mud} \text { pump) } \\
\text { Hydraulic fracturing: } 18 \mathrm{~h} \text {, Fuel consumption: } 0.19 \mathrm{~m}^{3} / \mathrm{h} \text { (high pressure pump), } 0.12 \mathrm{~m}^{3} / \mathrm{h} \text { (blender) }\end{array}$ \\
\hline
\end{tabular}

\subsection{Drilling works}

Calculated results of the spread of pollutants in the air during drilling work shows that the maximum hourly concentration of nitrogen oxides was $2661.8 \mu \mathrm{g} / \mathrm{m}^{3}$, sulphur oxides $0.018 \mu \mathrm{g} / \mathrm{m}^{3}$, particular matter $73.4 \mu \mathrm{g} / \mathrm{m}^{3}$, and for carbon monoxide $1129.2 \mu \mathrm{g} / \mathrm{m}^{3}$. The maximum annual concentrations for nitrogen oxides was $19.33 \mu \mathrm{g} / \mathrm{m}^{3}$, sulphur oxides $0.00013 \mu \mathrm{g} / \mathrm{m}^{3}$, particular matter $0.53 \mu \mathrm{g} / \mathrm{m}^{3}$ and carbon monoxide $8.19 \mu \mathrm{g} / \mathrm{m}^{3}$. The annual frequency of exceeding of nitrogen oxides was $2.23 \%$. The calculated $99.8 \%$ percentile of nitrogen oxides was $1673.1 \mu \mathrm{g} / \mathrm{m}^{3}$, for particular matter $46.1 \mu \mathrm{g} / \mathrm{m}^{3}$, and for carbon monoxide $709.7 \mu \mathrm{g} / \mathrm{m}^{3}$. All results of modeling the spread of pollutants in the air during drilling operations are presented in Table 5.

Analyzed data in Table 6 shows that for nitrogen oxides and particulate matter it is necessary to determine permissible emissions in the full range. For these substances, 
the condition specified in the shortened range of calculations of the levels of substances in the air $\Sigma S_{m m}=0.1 D_{1}$ was not met. In Table 6 the results of calculations in the shortened range.

Table 5

Calculation of pollutant concentrations during drilling operations

\begin{tabular}{|c|c|c|c|c|}
\hline \multirow{3}{*}{ Pollutant } & \multicolumn{2}{|c|}{ Emission } & \multirow{2}{*}{$\begin{array}{c}\text { Frequency } \\
\text { of exceeding } \\
P\left(D_{1}\right)\end{array}$} & \multirow[b]{2}{*}{$\begin{array}{c}\mathrm{S}_{99.8 \%} \\
\text { percentile }\end{array}$} \\
\hline & $\begin{array}{c}\text { Maximum } 1 \mathrm{~h} \\
\text { concentration } \\
S_{m m}\end{array}$ & $\begin{array}{c}\text { Maximum yearly } \\
\text { concentration } \\
S_{a}\end{array}$ & & \\
\hline & {$\left[\mu \mathrm{g} / \mathrm{m}^{3}\right]$} & {$\left[\mu \mathrm{g} / \mathrm{m}^{3}\right]$} & {$[\%]$} & {$\left[\mu \mathrm{g} / \mathrm{m}^{3}\right]$} \\
\hline $\mathrm{NO}_{2}$ & 2661.8 & 19.33 & 2.23 & 1673.1 \\
\hline $\mathrm{SO}_{2}$ & 0.018 & 0.00013 & 0.0 & 0.01 \\
\hline PM10 & 73.4 & 0.53 & 0.0 & 46.1 \\
\hline $\mathrm{CO}$ & 1129.2 & 8.19 & 0.0 & 709.7 \\
\hline
\end{tabular}

Table 6

Calculation of pollutant concentrations in the shortened range

\begin{tabular}{|l|c|c|c|}
\hline \multirow{3}{*}{ Pollutant } & $\begin{array}{c}\text { Emission drilling } \\
\text { operations } \\
S_{m m}\end{array}$ & $\begin{array}{c}\text { Admissible value } \\
D_{1}\end{array}$ & \multirow{2}{*}{ Evaluation } \\
\cline { 2 - 3 } & {$\left[\mu \mathrm{g} / \mathrm{m}^{3}\right]$} & {$\left[\mu \mathrm{g} / \mathrm{m}^{3}\right]$} & \\
\hline $\mathrm{NO}_{2}$ & 2661.8 & 200 & $0.1 D_{1}<S_{m m}<D_{1}$ \\
\hline $\mathrm{SO}_{2}$ & 0.018 & 350 & $0.1 D_{1}<S_{m m}<D_{1}$ \\
\hline $\mathrm{PM} 10$ & 73.4 & 280 & $0.1 D_{1}<S_{m m}<D_{1}$ \\
\hline $\mathrm{CO}$ & 1129.2 & 30000 & $S_{m m}<0.1 D_{1}$ \\
\hline
\end{tabular}

Figures 1 and 2 show graphical results of modeling the spread of pollutants in the air during drilling operations for vertical and horizontal well in relation to the maximum hourly concentrations.

Table 7 presents results of the maximum annual emission calculation during drilling operations as well as average yearly concentration reduced by the background. PM10 and $\mathrm{NO}_{2}$ are considered to meet the conditions set out in the full range of air substance levels. 


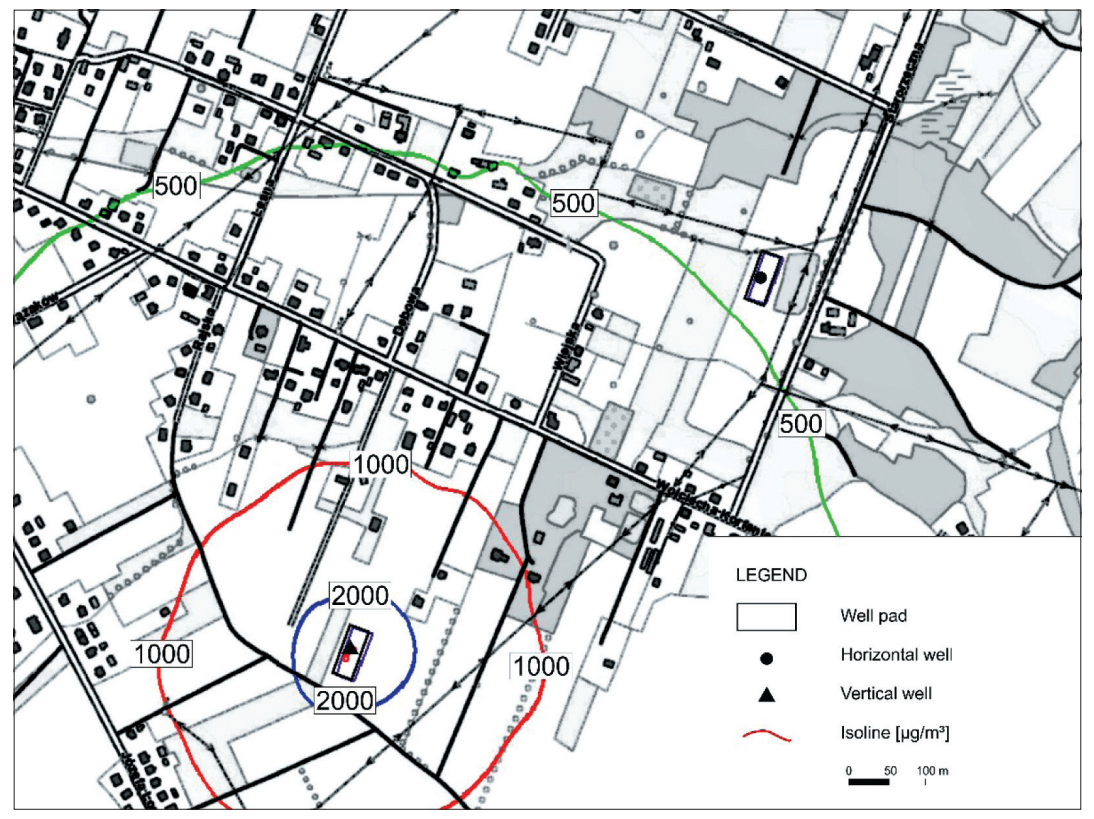

Fig. 1. Spatial distribution of $\mathrm{NO}_{2}-$ maximum 1 hour $\mathrm{NO}_{x}$ concentration during vertical drilling

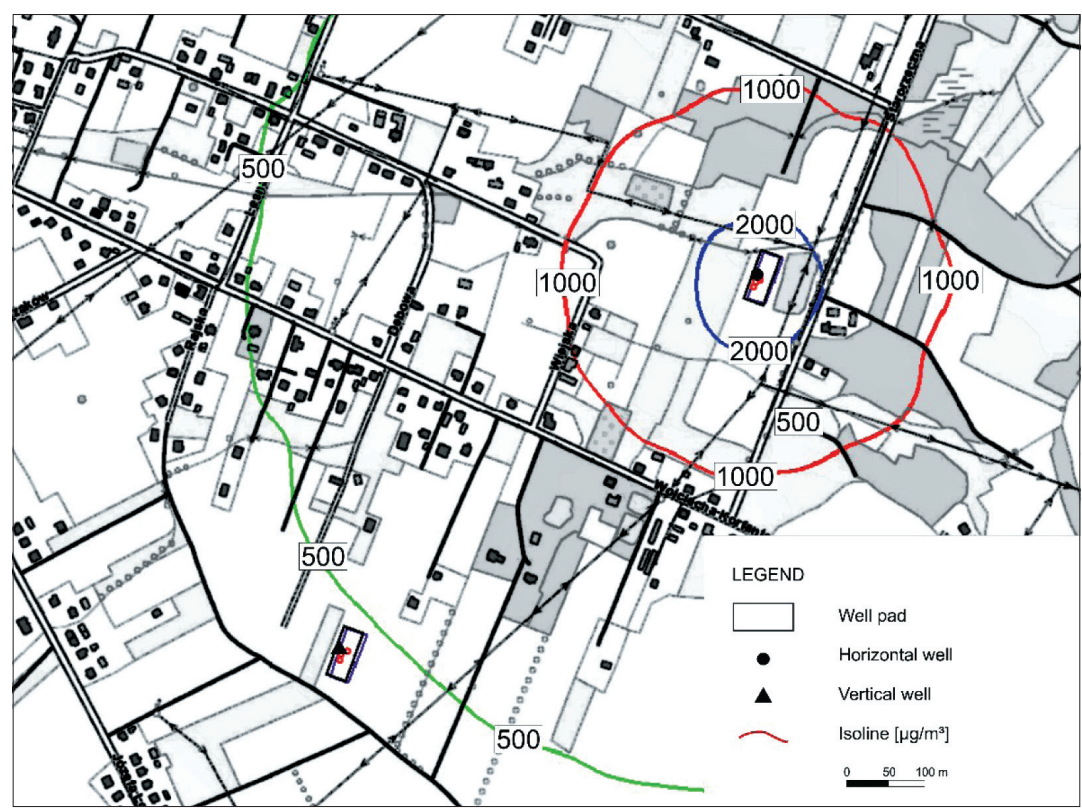

Fig. 2. Spatial distribution of $\mathrm{NO}_{2}-$ maximum 1 hour $\mathrm{NO}_{x}$ concentration during horizontal drilling 
Table 7

Calculation of pollutant concentrations in the full range

\begin{tabular}{|l|c|c|c|}
\hline \multirow{2}{*}{ Pollutant } & $\begin{array}{c}\text { Calculated emission } \\
S_{a}\end{array}$ & $\begin{array}{c}\text { Average yearly concentrations } \\
\text { reduced by the background value } \\
{\left[D_{a}-R\right]}\end{array}$ & \multirow{2}{*}{ Evaluation } \\
\cline { 2 - 3 } & {$\left[\mu \mathrm{g} / \mathrm{m}^{3}\right]$} & {$\left[\mu \mathrm{g} / \mathrm{m}^{3}\right]$} & \\
\hline $\mathrm{NO}_{2}$ & 19.33 & 20 & $S_{a}<D_{a}-R$ \\
\hline PM10 & 0.53 & 15 & $S_{a}<D_{a}-R$ \\
\hline
\end{tabular}

Figure 3 presents graphical results of modeling the spread of pollutants in the air during drilling operations vertical and horizontal wells in relation to the maximum annual concentrations.

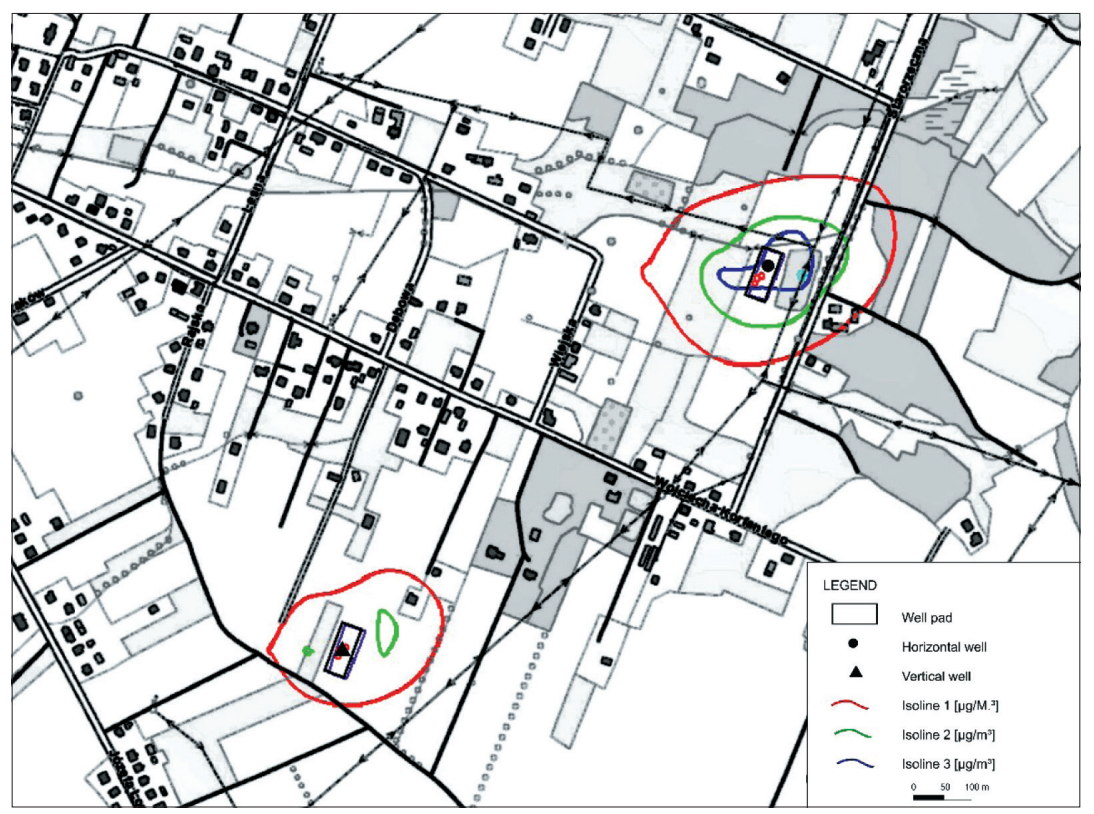

Fig. 3. Spatial distribution of $\mathrm{NO}_{2}-$ maximum yearly $\mathrm{NO}_{x}$ concentration during drilling operations

The analysis of the results of calculations of the annual frequency of exceedances of substances in the air shows that this condition was not met in relation to nitrogen oxides. Table 8 presents the results of the annual frequency of exceeding for nitrogen oxides for the drilling phase. 
Table 8

Calculation of frequency of exceeding

\begin{tabular}{|c|c|c|c|}
\hline \multirow{3}{*}{ Pollutant } & $\begin{array}{c}\text { Frequency } \\
\text { of exceeding } \\
P\left(D_{1}\right)\end{array}$ & $\begin{array}{c}\text { Admissible value } \\
D_{1}\end{array}$ & \multirow{2}{*}{ Evaluation } \\
\cline { 2 - 3 } & {$[\%]$} & {$[\%]$} & \\
\hline $\mathrm{NO}_{2}$ & 2.23 & 0.2 & $P\left(D_{1}\right)<0.2$ \\
\hline
\end{tabular}

Subsequent calculations were carried out to $S_{99.8 \%}$ percentile concentration of 1 hour. $S_{99.8 \%}$ percentile was $212.43 \mathrm{~g} / \mathrm{m}^{3}$ and was higher than the allowable concentration. Table 9 shows the results of the $S_{99.8 \%}$ percentile calculation.

Table 9

Calculation of $S_{99.8 \%}$ percentile

\begin{tabular}{|c|c|c|c|}
\hline \multirow{3}{*}{ Pollutant } & $S_{99.8 \%}$ percentile & $\begin{array}{c}\text { Admissible value } \\
D_{1}\end{array}$ & \multirow{2}{*}{ Evaluation } \\
\cline { 2 - 3 } & {$\left[\mu \mathrm{g} / \mathrm{m}^{3}\right]$} & {$\left[\mu \mathrm{g} / \mathrm{m}^{3}\right]$} & \\
\hline $\mathrm{NO}_{2}$ & 1673.1 & 200 & $S_{99.8 \%} \leq D_{1}$ \\
\hline
\end{tabular}

\subsection{Hydraulic fracturing}

Calculations of the spread of pollutants in air during hydraulic fracturing operations of coal seams in Upper Silesia Coal Basin show that the maximum hourly concentration of nitrogen oxides was $15312.8 \mu \mathrm{g} / \mathrm{m}^{3}$, sulphur oxides $0.093 \mu \mathrm{g} / \mathrm{m}^{3}$, PM10 $414.96 \mu \mathrm{g} / \mathrm{m}^{3}$, and for carbon dioxide $6473.28 \mu \mathrm{g} / \mathrm{m}^{3}$. The maximum annual concentrations for $\mathrm{NO}_{2}$ was $3.45 \mu \mathrm{g} / \mathrm{m}^{3}, \mathrm{SO}_{2}-2 \cdot 10^{-5} \mu \mathrm{g} / \mathrm{m}^{3}, \mathrm{PM} 10-0.094 \mu \mathrm{g} / \mathrm{m}^{3}$ and $\mathrm{CO}-1.47 \mu \mathrm{g} / \mathrm{m}^{3}$. The annual frequency of exceeding for nitrogen oxides was $0.074 \%$ and for PM10 $-0.007 \%$, for the other analyzed substances there was no exceedance of the annual frequency of exceeding. The calculated $S_{99.8 \%}$ percentile for all substances was $0.0 \mu \mathrm{g} / \mathrm{m}^{3}$. All the results of modeling the spread of pollutants in the air during hydraulic fracturing operations are presented in Table 10.

Analyzed data in Table 11 shows that for nitrogen oxides, particulate matter and carbon dioxide, it was necessary to determine permissible emissions in the full range. For these substances, the condition specified in the shortened range of calculations of the levels of substances in the air $\Sigma S_{m m}=0.1 D_{1}$ was not met.

In Figure 4 graphical results of modeling the spread of pollutants in the air during hydraulic fracturing in relation to the maximum hourly concentrations are presented. 
Table 10

Calculation of pollutant concentrations in the shortened range

\begin{tabular}{|c|c|c|c|c|}
\hline \multirow{3}{*}{ Pollutant } & \multicolumn{2}{|c|}{ Emission } & \multirow{2}{*}{$\begin{array}{c}\text { Frequency } \\
\text { of exceeding } \\
P\left(D_{1}\right)\end{array}$} & \multirow{2}{*}{$\begin{array}{c}\mathrm{S}_{99.8 \%} \\
\text { percentile }\end{array}$} \\
\hline & $\begin{array}{c}\text { Maximum } 1 \mathrm{~h} \\
\text { concentration } S_{m m}\end{array}$ & $\begin{array}{l}\text { Maximum yearly } \\
\text { concentration } S_{a}\end{array}$ & & \\
\hline & {$\left[\mu \mathrm{g} / \mathrm{m}^{3}\right]$} & {$\left[\mu \mathrm{g} / \mathrm{m}^{3}\right]$} & {$[\%]$} & {$\left[\mu \mathrm{g} / \mathrm{m}^{3}\right]$} \\
\hline $\mathrm{NO}_{2}$ & 15312.8 & 3.45 & 0.074 & 0.0 \\
\hline $\mathrm{SO}_{2}$ & 0.093 & $2 \cdot 10^{-5}$ & 0.0 & 0.0 \\
\hline PM10 & 414.96 & 0.094 & 0.007 & 0.0 \\
\hline $\mathrm{CO}$ & 6473.28 & 1.47 & 0.0 & 0.0 \\
\hline
\end{tabular}

Table 11

Calculation of pollutant concentrations in the shortened range

\begin{tabular}{|l|c|c|c|}
\hline \multirow{2}{*}{ Pollutant } & Calculated emission $S_{m m}$ & Admissible value $D_{1}$ & \multirow{2}{*}{ Evaluation } \\
\cline { 2 - 3 } & {$\left[\mu \mathrm{g} / \mathrm{m}^{3}\right]$} & {$\left[\mu \mathrm{g} / \mathrm{m}^{3}\right]$} & \\
\hline $\mathrm{NO}_{2}$ & 15312.8 & 200 & $0.1 D_{1}<S_{m m}<D_{1}$ \\
\hline $\mathrm{SO}_{2}$ & 0.093 & 350 & $0.1 D_{1}<S_{m m}<D_{1}$ \\
\hline $\mathrm{PM} 10$ & 414.96 & 280 & $0.1 D_{1}<S_{m m}<D_{1}$ \\
\hline $\mathrm{CO}$ & 6473.28 & 30000 & $S_{m m}<0.1 D_{1}$ \\
\hline
\end{tabular}

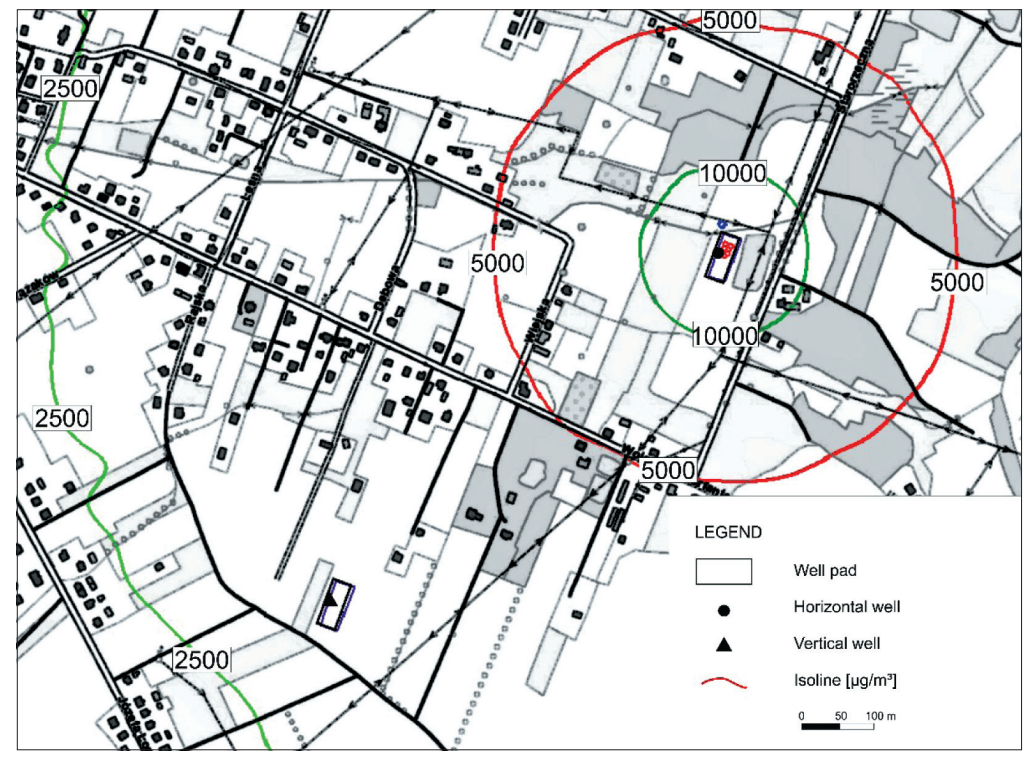

Fig. 4. Spatial distribution of $\mathrm{NO}_{2}-$ maximum 1 hour $\mathrm{NO}_{x}$ concentration during hydraulic fracturing 
Table 12 presents the results of the maximum annual concentration $S_{a}$ and reference values for the year reduced by the background and their assessment in relation to legal requirements. Particulate matter, sulphur dioxide and nitrogen oxide met conditions specified in the full range of calculation.

Table 12

Calculation of pollutant concentrations in the full range

\begin{tabular}{|l|c|c|c|}
\hline \multirow{3}{*}{ Pollutant } & $\begin{array}{c}\text { Calculated emission } \\
S_{a}\end{array}$ & $\begin{array}{c}\text { Average yearly concentrations } \\
\text { reduced } \\
\text { by the background value } \\
{\left[D_{a}-R\right]}\end{array}$ & \multirow{2}{*}{ Evaluation } \\
\cline { 2 - 3 } & {$\left[\mu \mathrm{g} / \mathrm{m}^{3}\right]$} & {$\left[\mu \mathrm{g} / \mathrm{m}^{3}\right]$} & \\
\hline $\mathrm{NO}_{2}$ & 3.45 & 20 & $S_{a}<D_{a}-R$ \\
\hline $\mathrm{PM} 10$ & 0.094 & 15 & $S_{a}<D_{a}-R$ \\
\hline $\mathrm{CO}$ & 1.47 & 0 & $S_{a}<D_{a}-R$ \\
\hline
\end{tabular}

In Figure 5 graphical results of modeling the spread of pollutants in the air during hydraulic fracturing in relation to the maximum annual concentrations.

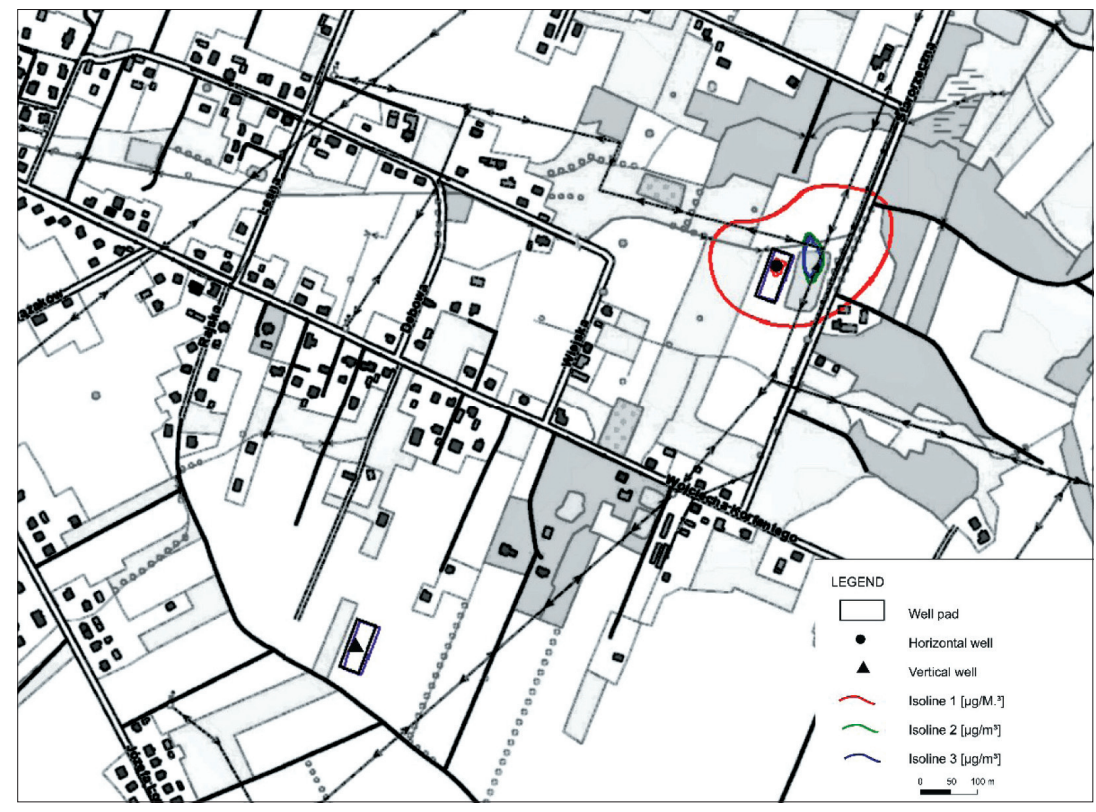

Fig. 5. Spatial distribution of $\mathrm{NO}_{2}-$ maximum yearly $\mathrm{NO}_{x}$ concentration during hydraulic fracturing 
Analysis of the results of calculations of the annual frequency of exceedances of substances in the air shows that the condition was met for all analyzed substances.

\section{CONCLUSION}

Methane from coal seam is extracted using the drilling technology. In order to increase extraction of methane, hydraulic fracturing operations should be carried out. These works should be carried out in such a way that air quality will not deteriorate. The results of modelling of propagation of contaminants during drilling and hydraulic fracturing operations shows that nitrogen oxides are the main substance that has a negative impact on air quality. In the case of using combustion engines to drive the drilling rig, air quality standards in the immediate area of their operation have not been met. The other pollutions generated during drilling and hydraulic fracturing operations do not create important hazard for the quality of air.

\section{REFERENCES}

[1] Exalo Drilling S.A.: Materiały firmowe.

[2] Hadro J., Wójcik I.: Metan pokładów węgla: zasoby i eksploatacja. Przegląd Geologiczny, vol. 61, nr 7, 2013, pp. 404-410.

[3] Jureczka J.: Kopalnie węgla kamiennego i... metanu? Doświadczenia ze szczelinowania pokładów węgla. 2018. Avaiable: https://www.pgi.gov.pl/dokumenty-pig-pib-all/aktualnosci-2017/4595-metan-kopalniany-janusz-jureczka/file.html [access: 4.04.2018].

[4] Kędzior S.: Potencjał zasobowy metanu pokładów węgla w Polsce w kontekście uwarunkowań geologicznych. Gosp. Sur. Min., 24 (4/4), 2008, pp. 155-173.

[5] Ministerstwo Ochrony Środowiska, Zasobów Naturalnych i Leśnictwa: Wskaźniki emisji substancji zanieczyszczających środowisko wprowadzanych do środowiska w procesie energetycznego spalania paliw. Warszawa, kwiecień 1996.

[6] Rozporzadzenie Ministra Środowiska z dnia 26 stycznia 2010 r. w sprawie wartości odniesienia dla niektórych substancji w powietrzu. Dz.U. $2010 \mathrm{nr} 16$ poz. 87.

[7] Rozporządzeniach Ministra Środowiska z dnia 24 sierpnia 2012 r. w sprawie poziomów niektórych substancji w powietrzu. Dz.U. 2012 poz. 1031.

[8] Trybuna Górnicza: Gilowice: dużo gazu z pokładu węla w projekcie Geo-metan. Available: http://nettg.pl/news/146184/gilowice-duzo-gazu-z-pokladu-wegla-w-projekcie-geo-metan [access: 4.04.2018]. 
[9] United Oilfield Services Sp. z o.o.: Materiały firmowe.

[10] U.S. Environmental Protection Agency: Large Stationary Diesel and All Stationary Dual-fuel Engines, Volume I, Chapter 3: Stationary Internal Combustion Sources. 5th ed. AP 42, 2013.

[11] WHO Global Urban Ambient Air Pollution Database (update 2016).

[12] Wojewódzki Inspektorat Środowiska w Katowicach: Raport o stanie środowiska w województwie śląskim w 2016 r. 